\title{
MANAGING MODERN SOCIAL CONFLICT THROUGH MIXED ETHICAL FOUNDATIONS: DEONTOLOGY, CONSEQUENTIALISM, AND VIRTUE ETHICS AS PILLARS OF SALVADOR GINER'S REPUBLICANISM
}

\author{
Manejar el conflicto social moderno mediante fundamentos éticos mixtos: la \\ deontología, el consecuencialismo y la ética de la virtud como pilares del \\ republicanismo de Salvador Giner \\ Paul Cella \\ Our Lady of the Lake University \\ pfcella@ollusa.edu
}

\begin{abstract}
:
A few years before his death in 2019, Salvador Giner noted the extreme difficulty of durably realizing the "precarious state" of social concord and the relative ease with which societies experience "a natural state" of discord. So he recalled his decades-long intellectual project of developing a republican political theory that seeks optimal social relations while pessimistically assuming the inevitability of discord. This article argues that Giner's pessimistic outlook is evinced through the heterogeneous ethical philosophical theories deontology, consequentialism, and virtue ethics - he proposes as guiding principles of republicanism. These theories must necessarily coexist, though they are ultimately incompatible.
\end{abstract}

\section{Keywords:}

Salvador Giner, republicanism, deontology, consequentialism, virtue ethics

\section{Resumen:}

Pocos años antes de su muerte en 2019, Salvador Giner hizo notar la extrema dificultad de realizar de manera duradera el "estado precario" de la concordia social y la relativa facilidad con que las sociedades experimentan "un estado natural" de discordia. Así aludía a un largo proyecto intelectual suyo, que consistía en desarrollar una teoría política republicana que permitiera lograr relaciones sociales óptimas mientras asumía, con pesimismo, la inevitabilidad de la discordia. Este artículo sostiene que la perspectiva pesimista de Giner se hace evidente por medio de las heterogéneas teorías ético-filosóficas —la deontología, el consecuencialismo y la ética de la virtud-que este propone 
como principios rectores del republicanismo. Dichas teorías han de coexistir necesariamente, pese a ser incompatibles en última instancia.

\section{Palabras clave:}

Salvador Giner, republicanismo, deontología, consecuencialismo, ética de la virtud

Recibido: $13 / 05 / 2020$

Aceptado: 17/11/2020

\section{Introduction}

A few years before his death in 2019, Salvador Giner noted the extreme difficulty of durably realizing the "precarious state" of social concord and the relative ease with which societies experience "a natural state" of discord. ${ }^{1}$ So he recalled his decades-long intellectual project of developing a republican political theory that seeks optimal social relations while pessimistically assuming the inevitability of disagreement $(2014,10)$. Giner was thus also eschewing calls for concord from conservatives, who typically preach interclass cooperation, and from those progressives who explain disharmony as an epiphenomenon of deficient social structures, whose fundamental alteration could enable harmony's actualization.

Giner's republicanism is more skeptical. It presupposes that modern societies — despite containing the desirable traits of being "relatively liberal, democratic and secularized" $(2002,45)$ - are essentially characterized by irreducible conflict. And conflict, for its part, stems from the fact that the typical person living in such societies holds an internally contradictory set of political values: freedom, equality, and solidarity. Thus, Giner's definition of modern society seems to have become more complex than that of his erstwhile collaborator Manuel Pérez Yruela, who not long ago defined modern society (much as he and Giner had once done jointly) as one that is "corporatized, organized, divided between those who rule and obey," and in which "tendencies derived from the hegemony of collective actors, the growth of organizations, hierarchical structures and imperative forms of coordination [. . . ] have durably taken root" (145). As a system fit to manage the problems that are likely to arise in his relatively more complex modern societies, Giner defends republicanism, because it is "the only solution [. . .] to the problem of rendering compatible modern man's three opposing, yet equally intense, aspirations: to be free, that everyone should be equal, and that all people show equal solidarity toward one another" (1996a, 181).

This article explores Giner's attempts to solve the puzzle posed by conflict. In focusing on Giner's political theoretical work, I seek not only to confirm Ramón Vargas-Machuca

${ }^{1}$ Unless otherwise indicated, all translations are mine. 
Ortega's assertion that this subset of Giner's oeuvre contains "a complete, consistent, and distinct normative project" (39). I also attend to a part of Giner's intellectual output that has understandably received less scholarly attention than his strictly sociological writings. This article's political theoretical focus should thus serve to complement Miguel Beltrán Villalva's analysis of Giner's efforts to resolve tension between sociology's "humanistic tradition" and its status as a "social science" (28), J. David Tàbara's emphasis on an "environmentalist" (237) reading of Giner's sociology, and such tributes to Giner's enormous stature among Spanish sociologists as Elías Díaz's elegy to this "sociologist with charisma" (109), Alberto Moncada's allusion to Giner as a leader among Spain's "elder sociologists" (129), or Helena Béjar's lauding of her colleague's "sociological intelligence" (261).

For my part, I will argue that Giner's conviction that contemporary political theory must assume that modern societies — which are founded on principles of individual rights and tolerance of social difference- must enable the realization of everyone's capacity for selfgovernment. They must also accept the paradox entailed by attempts to reconcile Giner's 'three opposing aspirations': freedom, equality, and solidarity. This situation creates a paradox because these things tend toward mutual exclusion. The expression of one tends to hinder the expression of another. As Giner reasons, in a world "in which there was only liberty," it would be harder to achieve enduring solidarity. In such a world, in the best case, charity would depend on voluntary altruism, while the worst case would be an unchecked despotism, wherein, Giner warns, "the strong would rule over the weak" (1996a, 182).

Modern societies also trap citizens between irreconcilable forces of necessity (such as valuing social pluralism) and the right to enjoy untrammeled individual liberties, which, if exaggerated, can imperil social cohesion and, consequently, the very modern ideals they rely on, such as some measure of equality. For Giner, republicanism is the form of government best suited to deal with these competing factors. While assuming their necessary existence, republicanism alone starts from "a fully realistic, anti-utopian point of departure," upholding all of the factors without preferring one over another, as libertarianism upholds liberty over fraternity, or communism upholds equality over liberty $(1998,9)$.

Questioning Félix Ovejero Lucas's emphasis on Giner's alleged fixation on "the idea of a good society" (90), I argue that Giner's "anti-utopian," skeptical outlook is evinced through the heterogeneity of the ethical philosophical theories he proposes as republicanism's guiding principles. Giner bases his republicanism on three major approaches: (1) deontology (mainly Kantian ethics); (2) non-utilitarian consequentialism (i.e. a consequentialism whose primary criterion is not, as for Jeremy Bentham, the maximization of happiness, but the consequences of actions); and (3) virtue ethics, which typically draws on Aristotle. Although I do not intend to exaggerate the differences between the theories, which can be complementary, there are crucial distinctions, which I will sketch out below. Moreover, my argument should not rest on these theories' basic 
incompatibility. Rather, I underscore how Giner's drawing on them reveals his belief that viable modern societies necessarily include a delicate balance of (1) robust individual autonomy (which will find most appropriate ethical guidance in deontology and Kant); (2) some self-sacrifice that might result in common goods (hence, consequentialism), and (3) the development and preservation of communally shared traditions, which have been moral priorities at least since Aristotle argued, on Giner's reading, that political virtue depends on "the social fabric that makes it possible," and is realized most fully "in political community" $(2012,34-35)^{2}$

\section{Defining Deontology, Consequentialism, and Virtue Ethics}

Before taking up Giner's engagement with deontological, consequentialist, and virtue ethics, I should define these categories. Deontology is uniquely concerned with providing normative bases from which to evaluate the rightness of actions. It maintains that defining right action is more morally important than evaluations of the goodness of the consequences of actions. Taking the opposite approach, consequentialism typically posits a conception of the good, and argues that an action is right if it conduces to the relevant conception. Utilitarianism, which is doubtless the best-known kind of consequentialism, defines the good as happiness and the absence of pain. So, an action is good if it causes there to be greater general happiness or less general pain. Virtue ethics is an entirely different kind of moral theory, basing moral evaluation not on discrete actions but holistic assessments of personal character. Among virtue ethicists, the question of how to evaluate character varies. There are, however, two generally held views: a morally excellent person (1) optimally develops her character through engagement in a project whose standards are determined by a human community, not individually, and (2) is a functioning member of some such community.

In general, virtue ethics is an Aristotelian moral theory, assessing character by using two key Aristotelian concepts: eudemonia and areté. Eudemonia (or flourishing) is the condition of living things (human and non-human) that achieve the optimum expression of their being. Areté is the quality of having achieved eudemonia. As Aristotle writes in his Nicomachean Ethics, it is "the good and noble performance of [actions] performed in accordance with the appropriate excellence" (943). As an example of non-human eudemonia, Aristotle describes a plant, which optimally expresses its being by digging roots deeply enough into the ground to ensure stability and growing toward the sun. If a plant does this, it possesses areté. Human eudemonia should be understood in basically the same way. It consists of fulfilling a naturally endowed capacity for moral excellence, and morally excellent human beings are those existing in and contributing to a human community.

${ }^{2}$ Giner's gloss seems to capture the conviction Aristotle expresses in Book I of his Politics, where he writes that the "political community, which is the highest [good] of all, and which embraces all the rest, aims at good in a greater degree than any other, and at the highest good" (1127). 
Before examining how Giner founds his republicanism on his belief that all three theories are valid ways of morally evaluating social life, I should clarify why Giner's bringing them together is a symptom of his pessimistic view of modern life, rather than a fusion of otherwise compatible doctrines. These theories are not perfectly compatible, but ultimately mutually exclusive. Their general application to all states of affairs would yield, in at least some instances, irreconcilable moral judgments. So, to admit their necessary coexistence is to admit that social coexistence necessarily entails moral contradictions.

Recall that the three theories give moral priority, respectively, to right action, good consequences, and virtuous character. Let us, then, apply these theories' moral commitments to British philosopher Philippa Foot's famous "trolley problem" thought experiment. Each theory would approach this dilemma uniquely and draw conclusions incompatible with the others'. The situation can be described as follows. An out of control trolley is barreling down the tracks. Ahead, five people are tied to the rails, unable to move. You find yourself standing in the train yard, a safe distance away and next to a lever. If you pull this lever, you will divert the trolley to a different set of tracks, where there is one other person. You have two choices: (1) do nothing, and the trolley will kill the five people lying in its path, or (2) pull the lever, and thereby redirect the trolley so that it kills one person.

Our three theories may or may not generate identical answers, but it is more significant that each would counsel a different approach. Generally speaking, deontologists will conclude that you ought not to pull the lever, since doing so would amount to causing someone's death, an intrinsically wrong act. Consequentialists will argue (with or without misgivings) that you ought to pull the lever because the consequence of your action will be a net saving of lives. A typical virtue ethicist would approach the problem more complexly, likely saying something like 'it depends.' It depends on your socially-informed values, how your encounter with this dilemma figures into your life as a whole, or how it would be judged by your peers.

I stress that each theory prescribes fundamentally different questions. Deontology states that the right solution will come from the individual (making its Kantian connection clear). For consequentialism, the right solution is intrinsically irrelevant, as long as it brings about good consequences. And virtue ethics, revealing its grounding in Aristotle, states that the right solution, which should be informed by local truths, cannot result from impartial considerations. Giner's work implies that all three theories must coexist in an ideal republican system, and that to accept their coexistence is to accept the inevitability of moral conflict. In the trolley problem, as in politics, we must make decisions, and conflict is inevitable if fellow citizens find fault in our choices.

\section{Deontological Ethics: Kant and Rawls's Influence on Giner}

Giner is a self-declared Kantian ethicist. He sees morally justifiable political life as a generally liberal system in which the guiding moral principle is that each citizen is an autonomous rational subject who should treat all his fellows as equals. For Giner, citizens

OXÍMORA REVISTA INTERNACIONAL DE ÉTICA Y POLÍTICA NÚM. 18. ENE-JUN 2021. ISSN 2014-7708. PP. 83-106 doi: 10.1344/oxi.2021.i18.31511 
are "discrete individuals," whose free private action, in conjunction with everyone else's, will be the foundation of "all social institutions" in a stable society. And a stable society, in turn, should be held together not by any supra-individual entity (such as a state) but through the constant reaffirmation of a social contract, whereby individuals agree to behave in accordance with a rationally knowable moral duty (Arbós and Giner, 23).

Giner's Kantian ethical commitment should be understood as a philosophical attachment to the idea that ethical action is in accordance with one's deon, or duty. Thus, the question of what ethical duty is arises. Kant's deontology and contemporary Kantinspired liberal ethical theories (e.g. Rawls's) hold that one has a justified moral duty if one should find this duty theoretically acceptable. The task of grounding ethical duty as universally justifiable is typically done through a hypothetical appeal to reason that asks individuals to reflect on how one ought to treat others in an ideally just society. Giner has proposed such a thought experiment, which I will lay out after briefly looking at those of Kant and Rawls, two standard points of reference.

Kant establishes ethical duty in his categorical imperative, which prescribes that one should "act only according to that maxim by which you can at the same time will that it should become a universal law." Kant thus asks whether one would be right to act in a way in which one would not wish others to act, and specifically whether one would be right to lie and thereby "will [that lying] should become a universal law." Kant justifies a moral prohibition to lie, because no reasonable person would will that everyone should lie.

Rawls's rational agents discover moral duties by occupying his hypothetical "original position," in which they imagine themselves ignorant of their life circumstances (e.g. their social (dis)advantages) and subsequently attempt to define a just society. Rawls assumes that rational, self-interested individuals will choose a highly egalitarian society where the least well-off fare the best, because they will recognize that they might be burdened by considerable social disadvantages. This unbiased preference for minimum inequality is supposed to be sufficient justification for the establishment of the moral duty to contribute to the construction of a broadly equal society.

In his Carta sobre la democracia, Giner follows Kant and Rawls by introducing his own deontological thought experiment — his "parable of the political pact" — as "proof that democracy is the regime that is most acceptable to the majority" (22). ${ }^{3}$ Like his predecessors, Giner probes our moral intuitions by asking us to make a moral judgment from an artificially unbiased perspective. Specifically, he asks that we "imagine that, in a distant land, a great catastrophe leaves many dead," and that survivors "assemble to form a government." Giner asks what form of government we would choose. "Tyranny? Aristocracy? Anarchy? [. . .] Democracy?" Assuming that "most sensible people will choose neither one nor a few powerful lords to govern them, but will seek an alternative

${ }^{3}$ Giner also inserts himself in the liberal tradition through his essay's title, which recalls John Locke's Letter on Toleration. 
that better upholds their shared dignity," he reasons that there are "good reasons to defend the establishment of a democratic order" (22-23). Giner's "parable" contains clear Kantian and Rawlsian influences. Kant, Rawls, and Giner describe a position of impartiality that is supposed to lead to recognition of how we should act. We should obey the categorical imperative, in Kant's case. We should prefer rough equality in Rawls's. And we should be inclined toward popular government in Giner's.

Giner's Kantian-Rawlsian influence is also evident in his conception of the individual as essentially endowed with shared dignity and inalienable individuality. One cannot overemphasize the importance of these concepts — dignity and individuality — in the deontological tradition. In Kant, dignity has at least two meanings: (1) it is a property of free and separate individuals that autonomously prescribe universalizable moral laws; and (2) it is a quality possessed by individuals that are treated according to Kant's second categorical imperative, the so-called "Humanity Formula," which states that one should never treat others merely as means, but as ends in themselves. The importance of individuality and separateness in deontology is twofold. First, individuals are the primary sources of morally right judgments, which rely on the ability to reason unhindered by external influence. Therefore, the actualization of morally right states of affairs (like just societies) depends on everyone's capacity for the free use of reason. Second, the tradition holds that all rational individuals are potential sources of definitions of the good.

Thus, whereas consequentialism subordinates individual conceptions of goodness to some predetermined good outcome, and whereas virtue ethics makes the good dependent on holistic considerations of life circumstances, deontology holds that individuals define the good independently. They are limited only, as in Rawls's "original position" or Giner's "parable," by the rational acknowledgement of moral intuitions.

So, like Kant and Rawls, Giner argues that the cumulative action of free, rational individuals can generate a just society. Each person's rationally-motivated right actions and pursuit of privately-defined goods presumably lead to a polity containing both a shared conception of what is just and limitless conceptions of what is good. In Giner's words, if "the well-intentioned citizen demonstrates everyday his commitment to democracy," there will be sufficient foundation to guarantee "the future of democracy as a way of life" (1996a, 122). Modern societies should therefore preserve citizens' right to choose autonomously "their own, idiosyncratic path" (1996a, 158), because "a measure of solitude is necessary for the true expression of moral judgements" $(2002,88)$. And Giner's defense of just "a measure of solitude" is remarkably circumspect alongside his emphatic conviction that individual emancipation has historically enabled humanity's "greatest and most noble and original accomplishments" (1996a, 151).

However, although he believes autonomy should be a foundational principle of modern social life, Giner is ultimately skeptical about the compatibility of unrestricted liberty and justice. A political system made up of individuals pursuing privately-conceived ends in relative isolation may generate a society characterized by insufficient solidarity and, consequently, excessive inequality. 


\section{Questioning Deontology}

Before discussing Giner's ambivalence about individual liberty, let us consider what bearing it has on this article's main thesis. If Giner believes that individual liberty has only a limited capacity to found morally just societies, he must believe that deontology, too, is so limited. Individuals could not be the sole sources of definitions of the good, since the resulting irreducible pluralism will tend to undermine solidarity and equality. Giner's compensatory method for the social disequilibria that might flow from the conviction that individuals' rationally-motivated actions are the primary origin of justice is a sort of consequentialism that involves his positing forms of solidarity and equality as goods (or good consequences) to be pursued socially, not individually.

Before turning to Giner's consequentialist commitments, a closer examination of his ambivalence about individual liberty will help to better understand why he turns to consequentialism as a complement to his general theory. For Giner, individual liberty is a double-edge sword. Positively, Kant, Rawls, and Giner's thought experiments show that individuals can intuitively discover social duties. Assuming that such dutiful cooperation is possible, Giner admits that individuals should be let alone to interact freely in what he conventionally calls "civil society" $(2012,289)$. Giner defines this term as "an autonomous sphere of civil liberties" that, in normal circumstances, should be beyond the legal reach of any "political power" and all forms of "external interference." However, in practice, individuals in civil society —which Giner also defines unfavorably as "an assortment of groups organized for the exclusive advancement of their interest" - can fail to heed supposed intuitions. Specifically, they can hold biases not in favor of all, but only some of their fellows, and particularly toward those who share their concept(s) of the good or some private interest. ${ }^{4}$ Free individuals are thus as likely to cooperate disinterestedly as they are to pursue factional interests, "regardless of whether said interests benefit the general welfare" (1996a, 165). The result will be a situation where groups of free individuals with common interests are, problematically, free to impose their idea(s) on dissenters, possibly without regard for deontological obligations.

Giner believes that governmental policies, such as those protecting collective bargaining and the rights of workers to strike, can curb the worst abuses of power in civil society. However, it remains necessary to go beyond palliative strategies to attack the presumption that society should be morally "neutral," or constituted only by agreements between private individuals and groups. Giner's attack is twofold. First, he argues that it may be irrelevant whether proponents of "the open society" $(1998,4)$-which, as Karl Popper described it, "sets free the critical powers of man" and makes us "the makers of our fate" $(3 ; 5)$ - are sincerely committed to liberty, since it seems that, whatever the theoretical value of individual liberty, the free rein given to individuals in civil society has harmful effects in practice. For example, it may enable a limitless accumulation of wealth

\footnotetext{
${ }^{4}$ As harmful examples of such anti-social biases, Giner references The National Rifle Association
} (USA) and the international financial and tobacco industries (1996a, 165). 
without regard for others' wellbeing. Therefore, a morally neutral liberalism is at least compatible with an "unbridled capitalism." And, because capitalism entails unequal access to capital, it will require the crystallization of "inter-class boundaries."

Unbridled individualism results in the consolidation of power by dominant private groups. Weaker classes must compete with their powerful peers as merely theoretical equals. Worse still, practical inequality will endure as a necessary structural component in civil society, one of whose essential elements - contractual agreements - can exist only where an unevenness of fortune obtains. As Voltaire once wittily noted, only if inequality is a feature of a society can we explain the provision of services within it, because "if you need a pair of shoes, you won't have any luck asking a lawyer" (476-77). Voltaire concluded that equality is thus "enormously idealistic" and that, given inequality, unprivileged members of society "must do their duty," lest society become "perverted." If this is the case, then Popper's idealistic "pretense of neutrality" is, at best, naïve. At worst, he provides a cynical justification of privilege that self-servingly ignores Voltaire's realistic conclusion.

Also indicating a gulf between theory and practice, Giner's second line of attack is at once more sympathetic and more devastating. He makes the familiar observation that those interacting in the real world —unequal as they are in power and influence- are nothing like the theoretically equal persons imagined in Rawls's (and, by implication, Giner's own) abstract "elucubrations" (2012, 210). Although he quickly softens this criticism by recognizing that Rawls, unlike hardcore liberals like Popper, argued "powerfully in favor of equity," Giner's subsequent attack proves more damaging. Discrediting not only self-serving defenses of liberal individualism, but also Rawls and others' good-faith proposals, Giner assumes a basic human desire for robust moral bearings that are founded on ideas of "what is right and good" in some intrinsic, non-contractual sense $(2012,211)$. Such a desire can hardly be satisfied in a liberal system. Because liberalism is morally neutral, it is essentially "devoid of ethical convictions that go beyond the value of arriving at expeditious agreements."

For Giner, predictable consequences of the sort of dissatisfaction that is likely to arise in a liberal system will include, in the best case, resignation in the face of socio-economic inequalities. The worst consequences may include fanaticism caused by anger over social powerlessness. Regardless of the particular responses of citizens, Giner observes an evident dysfunction, or "moral dissonance," in a liberal society that stands for liberty and equality but presents a disconcerting separation "between theory and practice" (2012, 212). In other words, whether it is the product of cynicism, good intentions, or something else, it seems that deontological liberalism, by failing to bring theory and practice closer together, is always somehow incomplete. Therefore, it needs some moral complement.

Giner warns that an exceedingly uneven distribution of political power will lead to the transformation of shared, popular rule into what Robert Dahl called "polyarchy," or the rule of a select few (1-2). Civil society's conflicts tend toward the concentration of power into few, rather than all hands. Where power rests with all, there is democracy, in which 
the whole demos is sovereign. As Dahl presented the distinction, all those living in a democracy are "political equals" in a legal sense. So, they correspondingly "have their preferences weighed equally in the conduct of the government." In a polyarchy, the preferences of an influential minority are weighed disproportionately.

Despite finding Dahl's conceptual distinction between democracy and polyarchy useful, Giner is not ideologically close to Dahl. Indeed, Dahl considers that polyarchy might create conditions favorable to the stability of democracy, even if it is not favorable to democracy's conceptual purity as unmediated popular rule. In fact, Giner is closer to one of Dahl's critics, William Robinson, who dismisses stability as a political good if its price is, as Robinson thinks it is, "social control and domination" and "political disempowerment" (20-21). Giner goes further, arguing that civil society is logically consistent not only with uneven power distributions, but with "tyranny, or at least oligarchy" (2008a, 34). Drawing on Robert Michels's "iron law of oligarchy," Giner reminds us that, in a system essentially lacking "an institutional apparatus" (36) that can control the naturally unpredictable results of spontaneous interpersonal relations, inimical phenomena such as tyranny and oligarchy are not accidental. Rather, they are foreseeable "necessities," as Michels grimly reasoned (401).

On Giner's account, if deontology confines itself to prescribing individuals' just action and agnostically allowing individuals to pursue privately conceived goods, it will degenerate into lopsided struggles for political influence. Though created "for universal ends," deontology finally enables the opposite, the effective negation of common interest and the proliferation of "faction, egoism, and sectorial interest" (1996b, 261). Thus, deontology alone provides insufficient moral guidance for modern, pluralistic societies, which require more shared ideas of the good than an exclusively theoretical emphasis on justice can provide. So Giner, a self-proclaimed Rawlsian, nonetheless criticizes the "sterile vagueness" $(1992,28)$ of Rawls's positing the primary goods of ideal citizenship (namely basic rights and liberties) as allegedly insufficiently informed by real-world matters. Further, maybe Giner levels a similar charge of detachment against Kant —who wrote in On Perpetual Peace that "justice" should prevail, "though the world perish" when he writes that "fiat iustitia pereat mundus is but a show of irresponsibility" (139). Kant and Rawls might do well in attending to idiosyncrasies that demand pragmatic applications of justice.

Whereas Kant and Rawls's private individuals should be potential sources of ideas of the good, Giner supplements Kant's understanding of civil society with Hegel's to argue that they should not be the only such source. Characteristically, Giner finds appealing how Hegel dialectically works through "liberal individualism's deficiencies without falling prey to anti-individualism," to attain a synthetic "integration between individualism and universalism" (2012, 295). It is true that Hegel's civil society — which Hegel himself describes as a "territory [. . .] where there is free play for every idiosyncrasy [. . .] and where waves of every passion gush forth" (181) — is not clearly different from liberalism's. However, an important distinction derives from Hegel's reversal of liberalism's causal 
relationship between the state and civil society. The liberal assumption is that the state is only legitimate if civil society's members, who are posited as having existence prior to the state's formation, recognize it as such. Conversely, Hegel reasons that civil society "presupposes" some overarching structure (be it a state or something else), because "particularity" does not exist in a vacuum but is "conditioned" by "relations with other people." Thus Hegel does not establish a definition for any specific kind of governmental structure, as anti-statist critics such as Popper hold. Rather, he affirms the conceptual necessity of some such structure which, as Giner concurs, "makes civilized life possible" $(2012,296)$. For Hegel, members of civil society are not naturally endowed with a capacity for self-government. Whatever autonomy they enjoy is relative to and supported by given political arrangements.

Kant, Giner argues, rightly insisted that individuals' respect for abstract "principles of moral conduct" is essential to healthy political life. However, a theory of ethics should also turn this question around, as Hegel's does, to ask how a society might be constructed so that morally worthy actions are more likely. Giner draws on Hegel to reason that the individual, whatever her capacity for self-determination, is somehow conditioned by social circumstances $(2012,37)$. So, Giner's republic is "a dual political universe" (1996a, 142), where morality is a matter of private and public interest. It is private in its being committed to abstract Kantian "principles," or to providing all individuals with "a framework of neutral rules that enable and foster social life among people and groups with diverse interests and aspirations." But it is also public, because it should impress "a specific content onto people's culture, lives, and behavioural inclinations."

\section{Giner's Consequentialism}

In representing his general conviction that societies should possess some ethical foundation that is valued by all citizens, Giner's "specific content" of public morality exemplifies his subscription to ethical consequentialism. Let us recall that consequentialism begins by defining the good and then considers all actions contributing to that good's existence to be just. Let us also recall consequentialism's incompatibility with deontology. The two theories disagree regarding the source(s) of the good, and this disagreement means that, notwithstanding potential agreement, to accept their coexistence is to accept the inevitability of moral conflict. So, if Giner's republicanism is founded on deontological and consequentialist principles, it is also founded on the presupposition that his ideal political regime will contain basic contradictions.

Any consequentialist ethical theory must (1) give a definition of the good so that one can evaluate the justice of actions in terms of their contribution to that good's actualization and (2) explain why it holds this good to be generally desirable, rather than an arbitrary preference. Utilitarianism, a well-known consequentialist theory, can demonstrate how consequentialism takes these steps. Utilitarianism defines the good as happiness and the absence of pain, and it holds this good to be generally desirable because it is empirically verifiable that all humans desire to be happy and avoid pain. Before turning to Giner's consequentialism, I underscore that utilitarianism (like Giner) bases moral laws on 
empirical evidence. It defines the good as happiness because one can see that all people desire to be happy. Giner makes a similar move from empirical observation to moral judgment. This deduction of norms from facts is significant to this article's thesis because, in making the good not wholly dependent on the preferences of autonomous subjects, this element of Giner's ethics is incompatible with a deontological framework.

Giner takes the two necessary consequentialist steps. He defines the good as society's "common interest," or "the interest that forces the individual not to be attached only to her most immediate interests" (Giner and Camps 1998, 137). He also says that the observation of modern life justifies this definition. He observes, for example, that, given high degrees of division of labor and resulting interdependence between virtually all citizens, modern societies entail the moral duty of all to concern themselves with the general welfare. Writing on this necessary connection between individuals and society, Giner reasoned that, since "our condition is communal life," we cannot "live in isolation," and so are obliged to "think of others with gentleness and respect" (54).

Giner's argument is informed both by observation and an assumption about human nature. Mutual social responsibility is supposed to depend on humans' being naturally social animals. It is also based on the assumption that, although individualism suppresses social nature, humankind is driven by opposing tendencies toward egoism and universalism and so should be faithful to both: "faced with the centrifugal force that makes people want to develop their talents apart from, and sometimes even in opposition to, others, there is a contrary, centripetal force leading them to join communities" $(1998,113)$.

It is relevant to this article's thesis that Giner should derive moral norms from observable facts in the world. He argues that, given their social coexistence and lack of selfsufficiency, modern citizens ought to contribute to society's general betterment. Further, humankind's (certainly debatable) natural desire for social connection means we ought to make possible its general expression in society. Giner acknowledges that, by moving from fact to norm, he exposes himself to standard criticisms that it is logically inadmissible to move from what is to what ought to be. He also admits to deliberately setting logic aside not only because, presumably, our "moral nature" leads us to differentiate "what is from what ought to be" $(2012,19)$. He also does so on pragmatic grounds, to address social fragmentation produced by excessive individualism. A functioning society demands a common set of interests, or a "civil religion," as Giner put it in the Rousseau-inspired title of one of his articles (1993). Therefore, though it is "logically inadmissible" to "propose a profane religion," it is nonetheless reasonable to do so, as a necessary condition of society's viability $(1993,12)$.

\section{Tension between Public and Private Commitments}

However, Giner's thinking about how to hold society together by means of universally recognized, common interests must not make us forget his equally strong, if nuanced, individualism. In favoring neither individual nor communal methods of structuring modern societies, Giner understands himself as drawing on Max Weber, whom he interprets as 
grappling with the fact that "the imposition of universal values over individuals is as destructive as its opposite" $(2012,100)$.

Acknowledging that some kind of universal imposition is necessary, Giner is nevertheless more deferential to the delicate social conditions that might arise from moral disagreement between individuals. So he offers a partial, twofold solution that consists of individualistic (deontological) decisions that emanate into the public and a complementary, universally-defined (consequentialist) common interest, which can legitimately make moral demands on individuals. He admits that this proposal, particularly its second part, would practically undermine individual autonomy. He notes, for example, that if "common interest is ever clearly defined, the threat of totalitarianism and political terror is not far behind, because there is then no doubt that this is the interest that must be imposed" (1992, 28).

Nevertheless, if Giner heeds Weber's warning about the "totalitarian" destructiveness of communal demands, his dialectic between individualism and universalism continues. He optimistically presents possibilities where the German theorist expressed caution. He argues that, even if it is potentially damaging to steer society's course toward some common interest, "if human existence, and particularly human social life, is to have meaning, it needs a certain moral direction that must be defined collectively" $(1998,11)$. Giner is no doubt committed to robust personal freedoms, but he worries that if citizens absorb themselves in private affairs, two undesirable consequences will follow: (1) their lives will lack direction; and (2) they will not care about others' affairs.

Concerns about universalism notwithstanding, Giner's urges the cultivation of some common civic identity and purpose. He counsels the moderate weakening of private ties to make room for the impartiality necessary to feel concern for public welfare. For, as he reasons, "the weaker the bonds one has with group interests are, the greater the chances for impartiality" $(2002,88)$. It is doubtless desirable "to maintain and cultivate difference," as Giner concedes, but it remains true that absolute fidelity to private distinctions ignores the fact that "difference and inequality reinforce one another" (2003, 140). Again, Giner shows a basic commitment to individual liberty, but attends pragmatically to its practical insufficiency.

Characteristically, however, Giner does not paper over tensions between private and public. He opts instead for equanimity, promoting citizens' active participation in the parts of society that best reconcile these ever-competing tendencies. This includes charitable organizations and activist groups, which are, in Giner's words, "volunteer collections of citizens that join forces to resolve some social problem or satisfy some human need beyond the confines of a discrete social group" (1996b, 270). Such associations, belonging to an in-between space that Giner calls "lo privado público" (1995), ${ }^{5}$ are effective in

\footnotetext{
${ }^{5}$ I have left this phrase untranslated, so that Giner's original formulation is not lost. The phrase,
} which translates literally as 'the public private,' refers more idiomatically to those activities taking

OXÍMORA REVISTA INTERNACIONAL DE ÉTICA Y POLÍTICA NÚM. 18. ENE-JUN 2021. ISSN 2014-7708. PP. 83-106 doi: 10.1344/oxi.2021.i18.31511 
straddling the private-public divide in two ways. They constitute privately-organized groups with clear public dimensions. And they take the best from the private sphere (e.g. individual autonomy) and the public (e.g. concern for common interest), without being devoted entirely to either.

However, Giner sees that, if the "common interest" is merely an assortment of private goods, or an outcome of groups' being influenced by others' particular preferences, then it is indistinguishable from deontology's public moral agnostocism. Surely, Giner's common interest can be understood as emerging from public dialogue in that such interaction is a necessary condition for its taking shape. But Giner thinks it possible that interaction can also yield durable moral agreement that becomes a society's shared "luminous object of desire" (1996a, 56). Once such an 'object' is discovered, the justice of citizens' actions can be assessed, per consequentialism, in terms of whether they contribute to its realization.

Giner's republicanism is thus composed not of disengaged private citizens but ones who promote the common good and blur the line between private and public by assuming responsibility for others' problems. Turning Voltaire's famous critique of Leibniz's optimisme into his own gibe at today's individualism, Giner writes: "the task we all share and that consists of improving the world we inhabit can, in conditions of modernity, be no other than to cultivate our common garden" $(2002,79)$. For the same Voltairean Giner, the error of individualists is to proclaim their modernity while outmodedly ignoring that "our changing times have turned each individual's garden into our shared responsibility."

\section{Respecting Private Life while Promoting Public Life}

Although public-mindedness should abound in Giner's republic, such virtue may be hampered by two impediments. The first is humans' tendency to form exclusive communities that restrict concerns for public affairs. And the second is that many citizens lack the means to effectively practice civic engagement. Below, I examine the second obstacle. I will take up the first one later, when I discuss virtue ethics in Giner's thought.

place in the private sphere that have a public dimension. To give a clearer idea of the intellectual context in which Giner coined this term, it should be helpful to comment briefly on some especially relevant sources that are referenced in the 1995 article in which he developed it (see bibliography). For example, the "public" half of Giner's concept has obvious affinity with Benjamin Barber's defense of participatory politics in Strong Democracy (Giner 1995, 15). Giner fears that the private "third sector" (as theorized by Gidron, Kramer, and Salamon in Government and the Third Sector (1992) will prove excessively skewed in favor of private interests, and that it will thus not be as attentive to public needs as his ideal public-private balance should be (Giner 1995, 20). Finally, Giner seems to laud Paul and Miller's Beneficence, Philanthropy and the Public Good for advocating sufficiently healthy doses of "solidarity and solicitude" and "fraternity" to keep modern social life from, as he puts it, "succumbing to the destructive tendencies of civilized political life," notably the "modern world's massification" $(1995,13)$. 
In a typically republican manner akin to Aristotle, Machiavelli, and Rousseau, Giner notices an inverse relationship between inequality and public engagement. Consequently, he prescribes correctively limiting inequality to promote civic engagement among poor citizens, who are effectively "incapable of equal civic participation" $(2012,199)$. But abstract encouragement will not change the poor's "real possibilities" of becoming more politically involved. This project will demand governmentally sanctioned laws that create "propitious conditions for solidarity" and that specifically enable "generous and altruistic behavior" not through moral exhortation, but, materially, "through the redistribution of public resources for the benefit of the needy" (Giner and Camps 1998, 45).

Giner's consequentialism is here given another fruitful formulation: if greater civic engagement is good per se, then all means (e.g. policies) likely to promote it are just. Giner's rationale is two-fold. First, given a satisfactory level of social equality, citizens who experience a real capacity to effect change will be more likely to assume responsibility for general welfare. Second, citizens who assume responsibility for general welfare will be more likely to routinely set aside private interests for others' interests. A virtuous circle is thus created.

Further, if citizens enjoy rough equality as effective public actors, they can satisfy their dual (and arguably naturally human) tendencies toward particularism and universalism. Particular interests can be satisfied when, upon encountering their equals in public, citizens present private desires for change. Then, desires for universal connection can be satisfied when citizens (wanting to assume responsibility for a society that gives them a real capacity for effective public intervention) put private interests aside to discover what they can share with others. The result is the advancement of private interests and discovery of common ones. A richly complementary pair, the common can enrich the private if civically empowered citizens embrace as their own the interests they share with others, or in Giner's words, if they see "the problems, difficulties, and aspirations that the community confronts as situations that do not depend on fate, but on our will" (1996a, 143).

Complementarity between citizens' exercising universal concern without renouncing private integrity could prove a promising solution to discord. But Giner wonders whether this compromise is practically plausible. Recall Giner's belief that good republican government "can only take root in a shared political and moral culture" $(2003,1)$. Doubting that "citizens will generally be inclined toward civic virtue and fraternity" (1987a, 97), he worries that the ideal of universal citizenship based on shared values will prove too abstract to maintain. This will particularly be the case because universal citizenship will not typically offer desired, concrete, face-to-face human connections.

Faced with a dichotomy of abstract universality and tangible concreteness, Giner asks: although universal citizenship is essential to republicanism, might connections to immediate relationships (e.g. families, social organizations) be more important in constituting importantly firm ethical ground in an otherwise uncertain world? That is, might such connections be necessary where one yearns for what Giner calls the convictions that "clarify our lives, guide our behavior, and give things meaning" (2003, 
115)? Giner's ideas on these matters bear on how his republicanism is informed by virtue ethics, to which I now turn.

\section{Giner: Virtue Ethicist}

If virtue ethics primarily considers the context(s) of one's life and bases moral evaluations on contextually relevant criteria, deontology and consequentialism aspire to transcontextual, universal applicability. Kant's categorical imperative can be theoretically applied anywhere to determine rightness. Bentham's utilitarian Principle of Happiness can be similarly applied. Taking stock of relevant circumstances, virtue ethics asks what it means to do the right thing as, for example, a citizen of a given political system? What is good for a member of a specific religious faith? Is one performing a given practice optimally, in terms of the standards of a particular trade?

Virtue ethicists such as Susan Wolf claim that moral decisions should be grounded precisely in the intersection of circumstance and morality, which deontology and consequentialism too abstractly ignore. So, deontology and consequentialism advance an impoverished conception of human life that fails to account for the possibility that ideas of right and good do not admit of general applicability but are held by individuals in the pursuit of particular goals. In claiming that "it is misleading to insist that one is permitted to live a life in which the goals, relationships, activities, and interests that one pursues are not maximally morally good" (425), Wolf indicts deontology and consequentialism for their attachment to the idea that one's life might have moral worth if one does one's duty (deontology) or contributes to the good (consequentialism) but does not excel in shared, group endeavors. For Wolf, such neglect of particular projects for the sake of finding a universally applicable moral theory is inadmissible. To avoid such one-size-fits-all approaches, she thinks the good ought to be defined in tandem with such overarching life questions as: who am I? who do I want to be? and who (or what) is important to me?

Similarly, Joel Kupperman has suggested that deontologists and consequentialists, by ignoring such questions, are wont to evaluate one's behavior not as that of an individual with a distinct life trajectory, but as "an essentially faceless ethical agent who is equipped by theory to make moral choices that lack psychological connection with either the agent's past or future" (120). Kupperman's "faceless agent" alludes to his rival theories' attachment to conceptualizing all humans as capable of being morally judged according to the same criteria. It also indicates these theories' corresponding ignorance of humans' basically diverse moral goals, or, as Kupperman writes, of their different "past[s]" and "future[s]," which must be centrally considered in moral evaluation.

Another leading virtue ethicist, Alasdair Maclntyre, similarly argues that contexts, which he calls practices - and which he defines at length as "any coherent and complex form of socially established cooperative human activity through which goods internal to that form of activity are realised in the course of trying to achieve those standards of excellence which are appropriate to and partially definitive of that form of activity with the result that human power to achieve excellence and human conceptions of the ends 
and goods involved are systematically extended" (67) — are structures wherein humans internalize certain standards of excellence, which subsequently serve as morally relevant reference points for action. Maclntyre's position that particular life circumstances are necessary conditions for human moral excellence recalls Giner's conviction that real social connections will provide better ethical orientation than abstract rules. In effect, Giner would agree with Maclntyre and Michael Sandel, another philosopher associated with virtue ethics, who has written influentially that humans are most adequately understood not as "unencumbered" selves, free of attachments, but as essentially shaped by social circumstance. Giner would also have agreed with Montesquieu, whom he credits with calling attention to the previously unacknowledged "power of social circumstances" on personal character $(2002,46){ }^{6}$

\section{Tension between Autonomy and Community}

However, if Giner maintains that moral development is incomplete unless we free ourselves from what he calls "the chains of social conditioning," then it is unclear how his ideas about the moral relevance of Montesquieu's social circumstances fit in his republicanism $(2002,68)$. After all, Giner's republicanism relies ideally on some intercommunitarian morality that is independent of context. Nevertheless, for Giner, it remains the case that the modern Western philosophical tradition, which depends on what Descartes called "our own native intelligence, without [. . .] sensory experience" (222), overemphasizes reason's role in shaping moral judgment and underemphasizes the relevant role of community. And this despite the possibility that it is from community that "morality emerges," according to Giner (2012, 203). Modern philosophy has been excessively inclined toward conceptualizing humans as the sort of Cartesian "unencumbered selves" that Sandel criticized. The social relations of such humans are subject to what Giner disappointedly called "an ahistorical analysis," largely uninformed by contextual facts $(2012,113)$.

In a further challenge to modern thought's basic ahistoricism, Giner assumes that Descartes's "native intelligence" is not a product of dispassionate philosophical reflection on human nature. It is rather a self-serving projection of modern people, who happen to understand themselves as self-sufficient. Pressing his claim that proponents of selfsufficiency are disingenuous, Giner notes that "not even the most utopian rationalist has imagined an ideal human society made up solely of rational decision-makers, unfazed by social influence" $(2003,214)$. Although even Descartes may have abandoned his concept of purely rational persons in theorizing about human society, perhaps Descartes's liberal heirs are a more appropriate foil. Indeed, it would seem to be so if Benjamin Barber was right to call liberals "more Cartesian than Descartes," by which he meant that they thought

\footnotetext{
${ }^{6}$ Montesquieu takes up this theme in Book XXIX, Chapter XIV of The Spirit of the Laws, where he explains the differences between Ancient Roman law and that of his own $18^{\text {th }}$-century France by the fact that "the laws of Rome had not been made in the same circumstances as [those of France]" (384). And in Book XXVII, Chapter XIII he states more generally that "civil law is formed according to circumstance" (320).
} 
politics "could not be portrayed or understood in political terms but required antiseptic categories untainted by the subject matter that was to be their object"; i.e. untainted by the biases produced by real relationships (48).

Gemeinschaft vs. Gesellschaft

Regardless of whether the presupposition of self-sufficiency is a product of self-interest, Giner finds it misguided. It is unclear that humans - who, Giner observes, cannot "live without community bonds" $(2007,11)$ — prefer autonomy to the benefits of community membership. To further illustrate his criticism of modern conceptualizations of society and social relations, Giner draws on Ferdinand Tönnies's distinction between Gemeinschaft (community) and Gesellschaft (society). Gemeinschaft is a product of Giner's "social influence." It is a manifestation of Tönnies's Wesenwille, which is our essential will to be members of collective systems defined by common goods that, Giner argues, "connect us to people, nations, communities, tribes, and ethnicities" (2008b, 1293). In Gesellschaft, or voluntary associations, we behave as what Giner calls "rational decision-makers." We give expression to what Tönnies calls Kürwille, which is the rational will to, as Giner puts it, "satisfy some need or carry out our plans" in cooperation with persons outside our Gemeinschaft.'

In positing (as Hobbes does in his Leviathan) the individual as its basic structural component, modern society is a Gesellschaft. It is "purely associative," as Giner writes. It pushes Gemeinschaft to the background and thus harms communities whose members' common feature is not a shared rational motivation (like Hobbes's desire for selfpreservation), but such morally significant, non-rational ends as faith-based devotion. Hobbes's claim that an all-powerful sovereign has legitimacy only if the members of a society voluntarily grant it may ring true to modern intuitions. However, modern intuitions are not therefore generally Hobbesian, because any implication that all social facts arise from rational agreement may still seem wrong. Indeed, so they seem to Giner, for whom it is a "brute fact" that Gemeinschaft, not Gesellschaft, is the natural sphere of action for humankind, which he calls "essentially communitarian" $(2003,109)$.

Modernity's individualistic conception, with its origins in what Giner calls "the Cartesian belief in reason's supreme validity," has hindered the expression of this "fact" $(2002,66)$. It has kept us from seeing ourselves as members of particular groups. Despite this broadly Cartesian legacy, Giner argues that not only is it the case that "man's need for community ties has not been eliminated" $(2003,295)$. On the contrary, communal "connections that provide emotional and symbolic structure to our lives remain in high demand" (1987b, 182).

\footnotetext{
7 In Tönnies's own words, Gemeinschaft means "all kinds of social co-existence that are familiar, comfortable and exclusive" (18), while Gesellschaft refers to "life in the public sphere, in the outside world," or "a group of people who, as in Gemeinschaft, live peacefully alongside one another, but ... without being essentially united" $(18 ; 52)$.
} 
Although he calls attention to modernity's "high demand" for community, Giner is no nostalgic conservative. In fact, he describes himself as "conscious of the narrow meanness sometimes entailed by community membership, its prejudices and hierarchies" (2012, 109). He nonetheless reasons that, if a desire to form communities apparently persists in modern times, it is unacceptable to ignore this facet of human sociability in ethical theory. And it seems even less acceptable upon considering the dangerous possibility that Giner's 'demand' for community might be exploited by demagogues' cynically offering a sense of belonging to modern societies' atomized denizens by means of what Giner called "the tactical use of passion" (108).

\section{Categorical or Hypothetical Imperatives: Questioning Kant}

What is the moral relevance of the Gemeinschaft-Gesellschaft distinction? If there is high demand for the 'direction' and 'structure' of community, what are the moral implications of the coexistence of these two spheres, one of which arises from rational agreement and the other of which is bonded by custom? For the purposes of my argument, what is of greatest significance is that insofar as Giner sees community membership as necessary in moral development, he takes a decidedly anti-Kantian position. Whereas, for Kant, decisions for action originate in the mind, in Giner's community-oriented ethics, decisions about action are mediated by common standards.

To better understand this clash, consider Kant's distinction between categorical imperatives — which are general obligations applicable independent of circumstanceand hypothetical imperatives, which contingently pertain merely to one's or a group's desire to reach a given end. Giner, following Kant, is at least partially committed to universally applicable ethical rules. Recall, for example, his clearly Kantian "parable of the pact," whose aim is to duty-bind rational agents to upholding modern values. However, Giner's sympathies toward community-oriented ethics also commit him to the possibility of circumstantial moral commands, such as: 'if you aspire to $\mathrm{X}$, you should $\mathrm{Y}$,' or, more concretely, 'if you aspire to be a law-abiding citizen of Spain, you should respect Spanish laws.'

As virtue ethicist Philippa Foot once put it, "the desires on which a hypothetical imperative is dependent may be those of one man, or may be taken for granted as belonging to a number of people, engaged in some common project or sharing common aims" (308). The intention of making moral imperatives so conditional on particular circumstances is not to trivialize acts of apparently intuitive moral worth, like obeying just laws. Rather, it is to show that it is unclear how one could ground moral obligation irrespective of particular life projects. Backing away from his deontological commitments, Giner argues that our aspirations (or "desires," to use Foot's term) are, and should be, to some extent products of the communities to which we belong.

But if aspirations generate hypothetical imperatives, what generates aspirations? Giner responds: "beliefs," "shared mental configurations," or any "values, myths, practical and theoretical knowledge" that are important in shaping senses of self $(1997,55 ; 84)$. Any 
such collectively-held belief generates aspirations, or, quoting Giner, "incites or demands anyone who holds it to act according to it" (54). Returning to Kant and Foot's formulations of hypothetical imperatives, we might say that a labor union's belief that it deserves better working conditions will 'incite or demand' the adoption of strategies conducive to these ends. So, working backward, the original motivation for action can be found in beliefs, which originate not in individuals' minds, but in groups.

Giner's insistence that the beliefs of communities are causally related to actions is a direct challenge to the plausibility of Kant's rational agent, who can always act free of community-generated biases. While Kant's categorical prescriptions for right action imply that external influence on one's convictions will be either irrelevant (because practically inconsequential) or a source of essentially irrational bias, Giner complicates the idea that biases —or, as he would put it more charitably, firmly-held "beliefs" — are opposed to reason.

Giner dissolves Kant's opposition, allowing even false beliefs to be consistent with reason: "when someone believes something (however false) it is not irrational that he should conduct himself according to it" $(2012,171)$. And if it is true, as Giner states elsewhere, that "we frequently obey rules or have goals that result from our socialization," then only an excessively rigid Kantian assessment of action would fail to consider social conditioning $(1997,111)$.

Having doubted humans' status as unencumbered rational actors and suggested the absurdity of a society (like Tönnies's Gesellschaft) that is founded theoretically on autonomous rational agency $(1997,55)$, Giner takes on the complex task of evaluating actions by considering both a Kantian "rational component of beliefs" and sociallyinformed "reasons and goals that motivate action" $(2012,171)$. Given the moral relevance of group membership, moral assessments become messier than can be captured by any universal theory. After all, it is highly probable that a society will include "conflicting and mutually hostile behaviors," all of which must be granted, at least in principle, "a right to exist," regardless of whether they satisfy Kant's high ethical bar or any other general theory. Social life, for Giner, "is not only the result of a simple aggregation of innumerable, small interactions" $(1997,59)$. It is also an inherently conflict-ridden composition of "shared conceptions or beliefs about power, the economy, and proper behavior by people who belong to heterogenous and internally differentiated groups, ethnicities, classes, organizations, and institutions."

\section{Conclusion}

With these words in mind, we can fruitfully reformulate the puzzle that opened this article: "Democracy is the only solution we have found to the problem of rendering compatible modern man's three opposing, yet equally intense, aspirations: to be free, that everyone should be equal, and that all people show equal solidarity toward one another." How should we think of the pieces that make up a democratic citizenry? As individuals acting freely, the combination of whose actions amounts to what Giner calls "a simple 
aggregation of innumerable, small interactions"? As equal citizens? If so, what is the nature of their equality? If their equality is of a legal nature, does it overlook real differences, such as those related to social extraction or community membership? Or should a citizenry share a commitment to social solidarity? And if so, is it reasonable to expect solidarity to extend beyond the boundaries of private communities and relationships? For Giner, a good republic should do all these things. It should assemble free and equal individuals, some of whom will have overriding community loyalties, but all of whom ought to commit to mutual solidarity. Giner admits that such a solution's lasting viability will depend on a given society's ability to navigate between the divergent forces of "community and difference, belonging and separation, public life and private life," which are necessarily modernity's competing "internal logics" (Giner and Camps 1998, 122).

For Giner, the virtue of republicanism is that it promotes the robust civic engagement that enables otherwise very different citizens to discover common interests. It is thus capable of accounting for the paradoxes of modern life, or for our valued cultivation of private lives (with their diverse loyalties) and public lives (with its concomitant demand to set aside partialities for the sake of common goods). Rival political theories — such as liberalism, socialism, and communitarianism - put forward various theoretical certainties about what human political life should consist of. Republicanism, for its part, is appropriately less demanding. If liberalism makes protecting individual rights take precedence over all; if socialism maintains that equality and solidarity are paramount, and if communitarianism holds that communities' integral moral worth must be privileged, Giner's conciliatory response is that to be a republican means to champion liberal, socialist, and communitarian values without preferring any one set of them. Giner's compromise is not evidence of weak ambiguity. It is a firm conviction that modern social life is constitutively plagued by contradiction. We ought to be wary of any political theory that offers what he calls "simplistic and inapplicable formulas" to modern social life, which is "endemically conflictive" (1987a, 35).

This article has argued that Giner proposes to ease modern life's endemic conflict by bringing together moral prescriptions from three competing ethical theories: deontology, consequentialism, and virtue ethics. To the extent that modern individuals typically cannot renounce, and indeed ought firmly to embrace, individual liberty, the enjoinders that deontology places on their moral decision-making provide some degree of appropriate ethical guidance. However, deontology's indifference to the consequences of the actions it demands is likely to lead to a situation in which some notion of common good to which individuals' actions should contribute becomes desirable. A consequentialist ethical framework that is common across sectors of civil society can thus complement deontology's insufficiencies. And yet, humans' enduring need for community will consistently and predictably make it difficult to demand that they prioritize civic duties if these conflict with attachments to private groups or communities. Modern life cannot, therefore, fail to allow that moral decisions might be made based on a virtue ethical perspective, according to which the rightness of actions will depend in some measure on local truths. As the title of this article suggests, that Giner should subscribe to all three 
theories of ethics without apparent preference for any one of them is symptomatic of his conviction that modern social conflict cannot be definitively solved. It can only be managed through balanced, pragmatic recourse to moral prescriptions that will probably tend to counsel mutually exclusive definitions of right and wrong.

\section{Bibliography}

Aristotle (2001). The Basic Works of Aristotle. Ed. Richard McKeon. New York: Modern Library.

Barber, Benjamin. (1984). Strong Democracy: Participatory Politics for a New Age. Berkley: University of California Press.

Béjar, Helena. (2007). "Salvador Giner: la inteligencia sociológica." In Escritos sociológicos en homenaje a Salvador Giner. Eds. Manuel Pérez Yruela, Teresa González de la Fe and Teresa Montagut. Madrid: Centro de Investigaciones Sociológicas. pp. 261 76.

Beltrán Villalva, Miguel. (2007). "La sociología y el progreso de la conciencia sociológica." In Escritos sociológicos en homenaje a Salvador Giner. Eds. Manuel Pérez Yruela, Teresa González de la Fe and Teresa Montagut. Madrid: Centro de Investigaciones Sociológicas. pp. 25-38.

Dahl, Robert. (1971). Polyarchy: Participation and Opposition. New Haven: Yale UP.

Descartes, René. (1991). The Philosophical Writings of René Descartes: The Correspondence. Vol. 3. Trans. Cottingham, Stoothoff, Murdoch, and Kennedy. Cambridge UP.

Díaz, Elías. (2007). "Salvador Giner: un sociólogo con carisma." In Escritos sociológicos en homenaje a Salvador Giner. Eds. Manuel Pérez Yruela, Teresa González de la Fe and Teresa Montagut. Madrid: Centro de Investigaciones Sociológicas. pp. 109-18.

Foot, Philippa. (1972). "Morality as a System of Hypothetical Imperatives." Philosophical Review. 84, pp. 305-16.

Giner, Salvador. (1987a). El destino de la libertad. Madrid: Espasa-Calpe. . (1987b). Ensayos civiles. Barcelona: Edicions 62. . (1993). "La religión civil." Reis: Revista española de investigaciones sociológicas. 61, pp. 23-56. . (1995). "Lo privado público: altruismo y politeya democrática." Revista de Estudios Políticos. 88 (Abril-Junio), pp. 9-27. 
. (1996a). Carta sobre la democracia. Barcelona: Ariel.

. (1996b). "Altruismo y politeia democrática." Contrastes 1, pp. 259-82.

(1997). "Intenciones humanas, estructuras sociales: para una lógica situacional," in Cruz, Manuel (ed.) Acción humana. Barcelona: Ariel. pp. 21-126. . (1998). "Las razones del republicanismo." Claves de Razón Práctica 81, pp. 2-13.

. (2002). "La urdimbre moral de la modernidad." Anales de la Cátedra Francisco Suárez 36, pp. 63-100.

. (2003). Carisma y razón. Madrid: Alianza.

. (2007). "Dignidad cívica." Clave de Razón Práctica. 173, pp. 4-14.

. (2008a). "El destino de la sociedad civil." Revista Española del Tercer Sector.

10 (septiembre-diciembre), pp. 17-49.

. (2008b). "Hobbes, fundador de la concepción moderna de la ciudadanía," in Meil Landwerlin, Gerardo, and Cristóbal Torres Albero (eds.) Sociología y realidad social: libro homenaje a Miguel Beltrán Villalva. Madrid: CIS. pp. 128793.

. (2012). El origen de la moral. Barcelona: Península.

. (2014). "Dónde quedó la concordia." El Ciervo. 62 (748), pp. 8-13.

Giner, Salvador, and Victoria Camps. (1998). Manual de civismo. Barcelona: Ariel.

Hegel, G. W. F. (2008). Outlines of the Philosophy of Right. Trans. T. M. Knox. Oxford UP.

Kant, Immanuel. (1957). Perpetual Peace. New York: Liberal Arts.

. (1997). Critique of Practical Reason. Ed. and trans. Mary Gregor. Cambridge UP.

Kupperman, Joel. (1988). "Character and Ethical Theory." Midwest Studies in Philosophy. 13, pp. 115-25.

MacIntyre, Alasdair. (2007). After Virtue. University of Notre Dame Press.

Michels, Robert. (1915). Political Parties: A Sociological Study of the Oligarchical Tendencies of Modern Democracy. Trans. Eden and Cedar Paul. New York: Hearst's International Library Co.

Moncada, Alberto. (2007). "Los sociólogos mayores." In Escritos sociológicos en homenaje a Salvador Giner. Eds. Manuel Pérez Yruela, Teresa González de la Fe and Teresa Montagut. Madrid: Centro de Investigaciones Sociológicas. pp. 129-36.

Montesquieu. L'ésprit des lois. Paris: Gallimard, 1995.

Ovejero Lucas, Félix. (2007). "La sociología crítica." In Escritos sociológicos en homenaje 
a Salvador Giner. Eds. Manuel Pérez Yruela, Teresa González de la Fe and Teresa Montagut. Madrid: Centro de Investigaciones Sociológicas. pp. 89-108.

Pérez Yruela, Manuel. (2007). "Republicanismo y corporatismo." In Escritos sociológicos en homenaje a Salvador Giner. Eds. Manuel Pérez Yruela, Teresa González de la Fe and Teresa Montagut. Madrid: Centro de Investigaciones Sociológicas. pp. 145-57.

Robinson, William I. (1996). "Globalisation: Nine Theses on Our Epoch." Race and Class. 38 (2), pp. 13-31.

Sandel, Michael. (1998). Debating Democracy's Discontent. New York: Oxford UP.

Tàbara, J. David. (2007). "El pensamiento ambiental de Salvador Giner." In Escritos sociológicos en homenaje a Salvador Giner. Eds. Manuel Pérez Yruela, Teresa González de la Fe and Teresa Montagut. Madrid: Centro de Investigaciones Sociológicas. pp. 237 48.

Tönnies, Ferdinand. (2001). Community and Civil Society. Trans. Jose Harris and Margaret Hollis. Cambridge UP.

Vargas-Machuca Ortega, Ramón. (2007). "La huella de la tradición emancipatoria en Salvador Giner." In Escritos sociológicos en homenaje a Salvador Giner. Eds. Manuel Pérez Yruela, Teresa González de la Fe and Teresa Montagut. Madrid: Centro de Investigaciones Sociológicas. pp. 39-54.

Voltaire. OEuvres Complètes. Vol. 18. Paris: Garnier, 1878.

Wolf, Susan. (1982). "Moral Saints." Journal of Philosophy. 79 (8), pp. 419-39.

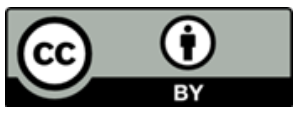

